\title{
A STUDY ON MODELLING AND SIMULATION OF PHOTOVOLTAIC CELLS
}

\author{
B.Sai Pranahita ${ }^{1}$, A. Sai Kumar ${ }^{2}$, A. Pradyush Babu ${ }^{3}$ \\ ${ }^{1}$ M.Tech Student, Dept of EEE, SRM University, Chennai, Tamilnadu, India \\ ${ }^{2}$ M.Tech Student, Dept of EEE, SRM University, Chennai, Tamilnadu, India \\ ${ }^{3}$ M.Tech Student, Dept of EEE, SRM University, Chennai, Tamilnadu, India
}

\begin{abstract}
This Paper presents a detailed study on the types of modelling of the PV Panel for simulation studies. The main concern of this study is to analyze the results and compare them under standard test conditions. PV systems are generally integrated with specific control algorithms in order to extract the maximum possible power. Hence it is highly imperative that the Maximum Power Point $(M P P)$ is achieved effectively and thus we need to design a model from which the MPPT algorithm can be realized in an efficient way. Also other parameters should be taken into account for finding the best model for the use in simulation. It is very important to choose the appropriate model based on the application. The models used for study in this paper include the single diode model, two diode model and Simscape modelling. MATLAB/Simulink presents a powerful tool to study such systems. The work tests the accuracy of the models under different temperature and irradiance conditions. The two diode model is known to have better accuracy at low irradiance levels which allows for a more accurate prediction of PV system performance. Simscape, part of Simulink environment, has a solar cell block that makes building a PV model straightforward and much easier programming with full demonstration to all system details. On the basis of the study, the best model that can be used for simulation purposes can be selected. It is envisaged that the work can be very useful for professionals who require simple and accurate PV simulators for their design. All the systems here are modeled and simulated in MATLAB/Simulink environment.
\end{abstract}

Keywords: PV cell, STC, MATLAB Simulink, Ideality Factor

\section{INTRODUCTION}

There are two major problems presently that the world is presently facing i.e. energy crisis and climate change .The environmental issues are caused mostly by the over reliability on the fossil fuels as the prime energy source for everyday activities. The increasing energy consumption due to the development of the technology is another major issue in the world both the problems can be overcome at the same time by introducing renewable energy sources. They play a very healthy part in building a "greener" and more sustainable energy for the plant. The renewable energy sources are clean, economical, abundant and the do not cause harm to the environment by emitting harmful $\mathrm{CO}_{2}$ gases. Solar energy, wind energy, hydro energy, geothermal energy, tidal energy and biomass are the sources of renewable energy. Out of all these energies, solar energy is the most reliable source since; sun is an infinite energy reservoir. The solar energy that hits the earth's surface in one hour is equivalent to the energy consumed by all human activities in a year. The sunlight is converted into electricity by using the photovoltaic effect.

Photovoltaic effect is a phenomenon through which a collection of light-generated carries by the P-N junction causes a movement of electron to the N-type side and holes to the P-type side of junction. This acts as a source of current. Due to the high cost of PV modules, optimal utilization of the available solar energy is imperative. This requires an accurate, reliable and comprehensive simulation of the designed system before installation. PV cell modeling is a very important factor that affects the output of the PV cell. Temperature $(T)$, Irradiance $(G)$, have influence on the open circuit voltage (Voc) and short circuit current (Isc) which determine the power generation.

\section{PV CELL MODELLING}

The simplest way of representing the solar cell is the single diode model. It consists of a current source in parallel to a diode. The parameters required are short circuit current $\left(\mathrm{I}_{\mathrm{sc}}\right)$, open circuit voltage $\left(\mathrm{V}_{\mathrm{oc}}\right)$ and the diode ideality factor (a). The ideality factor of a diode is a measure of how closely the diode follows the ideal diode equation. Due to the presence of recombination losses, ideality factor other than ideal are produced. The basic model is improved for accuracy by introducing the series resistance $\left(R_{s}\right)$.It does not prove to be efficient under temperature variations. To overcome this drawback, an additional shunt resistance $\left(\mathrm{R}_{\mathrm{p}}\right)$ is included. This increases the parameters to a considerable level and the computations are increased. Although $R_{p}$ is added, the model fails under low irradiation conditions.

To improve the accuracy, the two diode model is introduced where another diode is included in parallel to the already prevailing current source and diode. The addition of the diode leads to complexity. All the parameters need to be estimated and thus requires large computational time. Although greater accuracy can be achieved by this model, it requires the computation of seven parameters namely 
$\mathrm{I}_{\mathrm{pv}}, \mathrm{I}_{\mathrm{o} 1}, \mathrm{I}_{\mathrm{o} 2}, \mathrm{R}_{\mathrm{p}}, \mathrm{R}_{\mathrm{s}}, \mathrm{a}_{1}$ and $\mathrm{a}_{2}$. A three diode model of a solar cell has also been proposed taking into account the effect of large leakage current and also including the non-linearity of a solar cell.

Simscape is a tool provided by MATLAB which provides an environment for modelling and simulating physical systems spanning mechanical, electrical, hydraulic and other physical domains. Simscape components use physical connection to match the structure of the system being developed. Solar cell block in Simscape gives us a choice between two models containing eight parameters and five parameters respectively. In the latest version of MATLAB there is an option to set the number of series cells greater than one. This results in a more efficient simulation than if equations for each cell were simulated individually. Internally the block still simulates only the equipment for a single solar cell, but scales up the output voltage according to the number of cells.

\section{SIMULATION PARAMETERS}

A Single PV Cell is used for simulation for the study. The cells can be connected by increasing the number of cells in series and parallel based on the load requirement. The PV Cell specifications are as follows:

Table -1: PV Cell Specifications

\begin{tabular}{|l|l|}
\hline \multicolumn{2}{|l|}{ PV CELL SPECIFICATIONS $(0.8 \mathrm{~W})$} \\
\hline Open circuit voltage $\left(\mathrm{V}_{\mathrm{oc}}\right)$ & $0.541 \mathrm{~V}$ \\
\hline Short circuit voltage $\left(\mathrm{I}_{\mathrm{sc}}\right)$ & $1.464 \mathrm{~A}$ \\
\hline $\begin{array}{l}\text { Voltage at maximum } \\
\text { power }\left(\mathrm{V}_{\mathrm{mp}}\right)\end{array}$ & $0.453 \mathrm{~V}$ \\
\hline $\begin{array}{l}\text { Current at maximum } \\
\text { power }\left(\mathrm{I}_{\mathrm{mp}}\right)\end{array}$ & $1.28 \mathrm{~A}$ \\
\hline Maximum power $\left(\mathrm{P}_{\mathrm{max}}\right)$ & $0.58 \mathrm{~W}$ \\
\hline
\end{tabular}

The parameters of the Single Diode and Two Diode models used for simulations are as follows:

Table -2: Parameters of the Single Diode and Two Diode Models

\begin{tabular}{|l|l|l|}
\hline & $\begin{array}{l}\text { SINGLE DIODE } \\
\text { MODEL }\end{array}$ & $\begin{array}{l}\text { TWO DO } \\
\text { MODEL }\end{array}$ \\
\hline $\mathrm{I}_{\mathrm{sc}}(\mathrm{A})$ & 1.464 & 1.464 \\
\hline $\mathrm{V}_{\mathrm{oc}}(\mathrm{V})$ & 0.38 & 0.54 \\
\hline $\mathrm{I}_{\mathrm{mp}}(\mathrm{A})$ & 1.36 & 1.29 \\
\hline $\mathrm{V}_{\mathrm{mp}}(\mathrm{V})$ & 0.32 & 0.45 \\
\hline $\mathrm{I}_{\mathrm{O} 1} / \mathrm{I}_{\mathrm{O}}(\mathrm{A})$ & $3.727 * 10^{-7}$ & $2.46^{*} 10^{-6}$ \\
\hline $\mathrm{I}_{\mathrm{O} 2}(\mathrm{~A})$ & - & $6.329^{*} 10^{-6}$ \\
\hline $\mathrm{R}_{\mathrm{s}}$ & $1 \mathrm{e}-3$ & $1 \mathrm{e}-3$ \\
\hline $\mathrm{a}_{1} / \mathrm{a}$ & 1 & 1.6 \\
\hline $\mathrm{a}_{2}$ & - & 2.2 \\
\hline $\mathrm{K}_{\mathrm{i}}$ & 0.0017 & 0.0017 \\
\hline
\end{tabular}

\section{SINGLE DIODE MODEL}

The characteristic curves of PV cell in simulation environment can be realized using the fundamental equations. A single PV cell is realized as a current source placed in parallel with a diode and the output current equation is given as:

$$
I=I_{P V}-I_{O}\left[e^{\frac{q\left(V+I R_{g}\right)}{a k T}}-1\right]-\left[\frac{V+I R_{s}}{R_{p}}\right]
$$

Where,

$\mathrm{I}_{\mathrm{pv}}=$ photo voltaic current

$\mathrm{I}_{\mathrm{o}}=$ saturation current of the diode

$\mathrm{q}=$ electron charge in coulombs

$=1.602 * 10^{-19} \mathrm{C}$

$\mathrm{K}=$ Boltzmann constant

$=1.380 * 10^{-23} \mathrm{~J} / \mathrm{K}$

$\mathrm{a}=$ diode ideality factor

$\mathrm{R}_{\mathrm{s}}=$ series resistance

$\mathrm{R}_{\mathrm{p}}=$ parallel resistance

$\mathrm{T}=$ Temperature in Kelvin

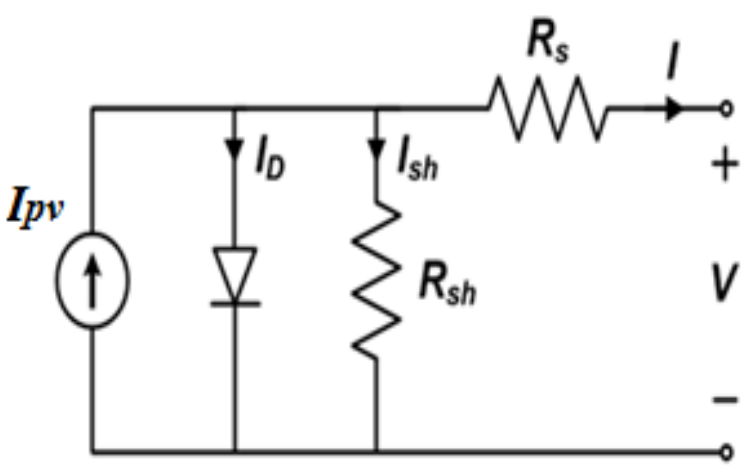

Fig -1: Equivalent Circuit of Single Diode Model

The photo voltaic current $\mathrm{I}_{\mathrm{pv}}$ is a function of the irradiance (G) and is formulated as:

$$
I_{P V}=\left[I_{P V \_} S T C+K_{i} \Delta T\right] \frac{G}{G_{S T C}}
$$

Where;

$\mathrm{I}_{\mathrm{PV}_{-} \mathrm{STC}}=$ light generated current under standard test conditions (STC)

$\Delta \mathrm{T}=\mathrm{T}-\mathrm{T}_{\mathrm{STC}}$ (in kelvin)

$\mathrm{G}=$ surface irradiance of cell $\left(\mathrm{W} / \mathrm{m}^{2}\right)$

$\mathrm{G}_{\mathrm{STC}}=1000 \mathrm{~W} / \mathrm{m}^{2}$

Irradiance under STC

$\mathrm{K}_{\mathrm{i}}=$ short circuit current coefficient

The diode saturation current $I_{0}$ is given as:

$$
I_{o}=I_{O_{-} S T C}\left(\frac{T}{T_{S T C}}\right)^{3} \exp \left[\frac{q E_{g}}{a k}\left(\frac{1}{T_{S T C}}-\frac{1}{T}\right)\right]
$$


Where;

$\mathrm{I}_{\mathrm{o}, \mathrm{stc}}=$ normal saturation current under standard test conditions (STC)

$\mathrm{T}_{\mathrm{STC}}=$ temperature under standard test conditions

$\mathrm{E}_{\mathrm{g}}=$ band gap energy of the semiconductor

The Matlab/Simulink implementation of the single diode model is as follows:

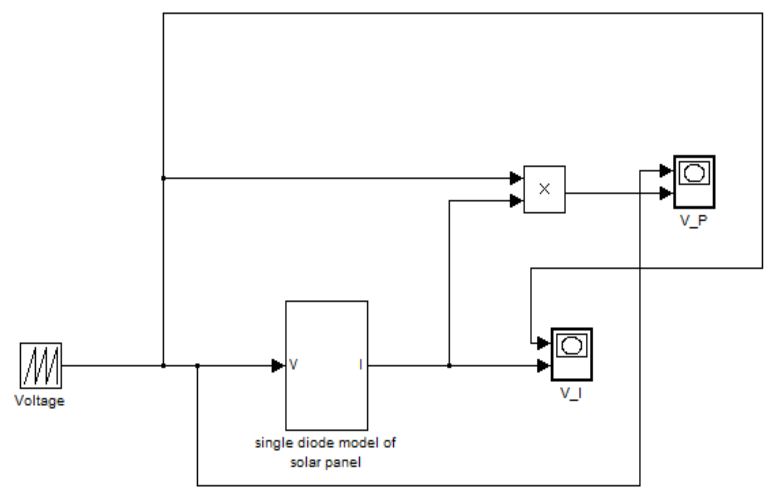

Fig -2: Single Diode Model Matlab/Simulink Implementation

The PV Characteristics under Varying Irradiance and Temperature for a single diode model are shown below:

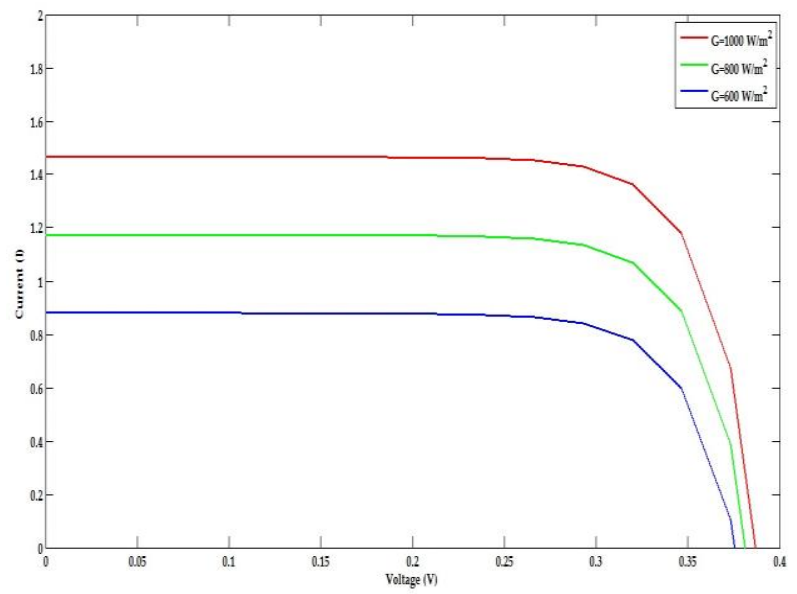

Fig -3: V-I Curve under varying Irradiance

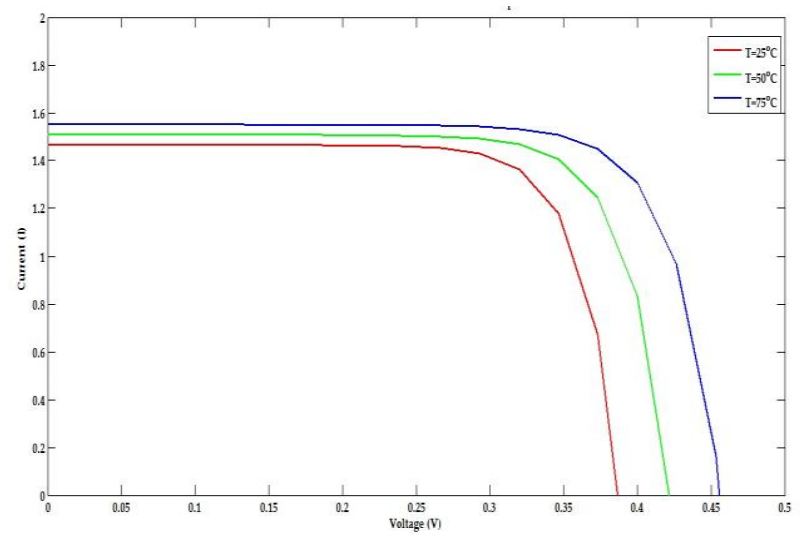

Fig -4: V-I Curve under varying Temperature
The Irradiance values given to the solar cell are $1000 \mathrm{~W} / \mathrm{m}^{2}$, $800 \mathrm{~W} / \mathrm{m}^{2}, 600 \mathrm{~W} / \mathrm{m}^{2}$ and the $\mathrm{I}_{\mathrm{sc}}$ values vary proportionately. The Temperature values given are $25^{\circ} \mathrm{C}, 50^{\circ} \mathrm{C}, 75^{\circ} \mathrm{C}$ and the $\mathrm{V}_{\mathrm{oc}}$ values vary with the temperature.

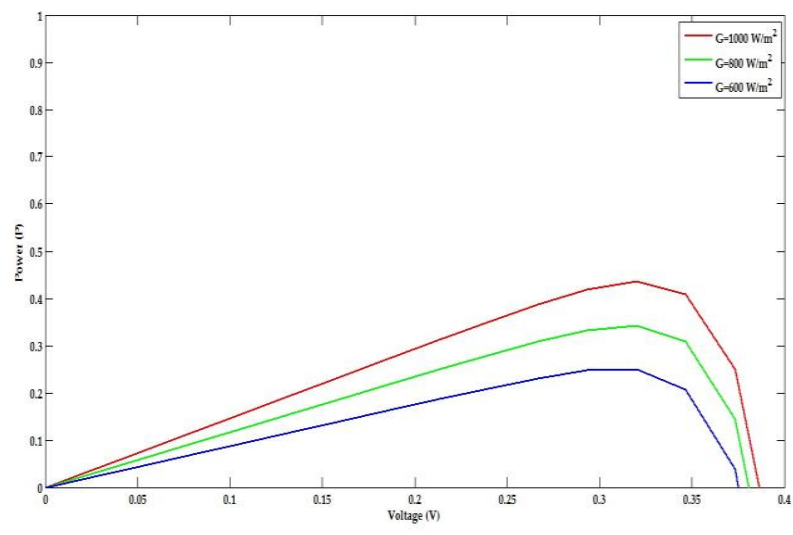

Fig -5: P-V Curve under varying Irradiance

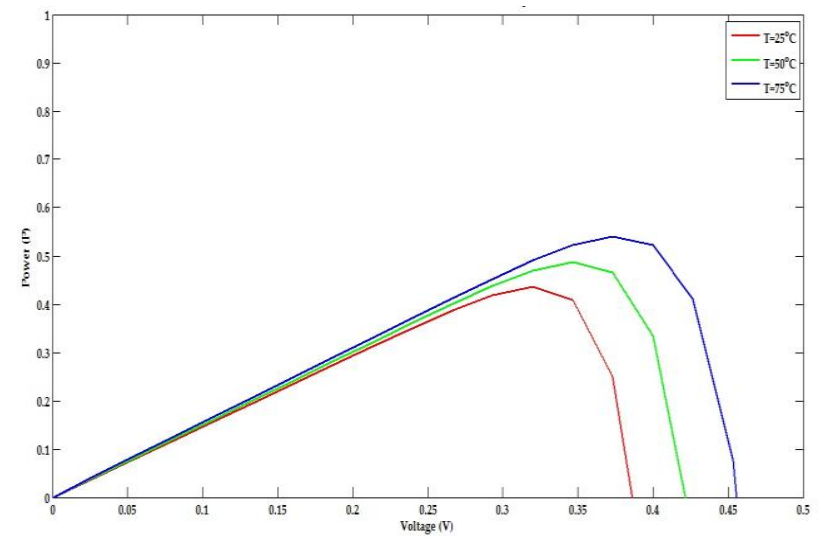

Fig -6: P-V Curve under varying Temperature

\section{TWO DIODE MODEL}

The single diode model was formulated based on the assumption that recombination loss in the depletion region is absent. In a practical solar cell, the recombination loss must be taken in to account and thus this leads to a more definite model known as the two diode model. The output current equation is given as:

$$
I=I_{P V}-I_{D 1}-I_{D 2}-\left(\frac{V+I R_{s}}{R_{p}}\right)
$$

Where $I_{D 1} \& I_{D 2}$ are the diode currents of the two diodes respectively given as:

$$
\begin{aligned}
& I_{D 1}=I_{01}\left[\exp \left(\frac{q\left(V+I R_{s}\right)}{a_{1} k T}\right)-1\right] \\
& I_{D 2}=I_{02}\left[\exp \left(\frac{q\left(V+I R_{s}\right)}{a_{2} k T}\right)-1\right]
\end{aligned}
$$




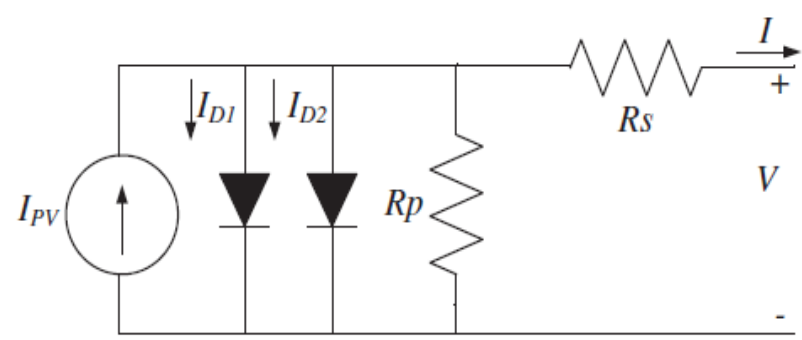

Fig -7: Equivalent Circuit of Two Diode Model

$\mathrm{I}_{\mathrm{O} 1} \& \mathrm{I}_{\mathrm{O} 2}$ are saturation current of the two diodes respectively. The simplified equations to determine the diode saturation currents are as follows:

$$
I_{01}=I_{02}=\frac{\left(I_{S C_{-} S T C}+K_{i} \Delta T\right)}{\exp \left[\frac{V_{\text {oc } S T C}+K_{v} \Delta T}{\left\{\left(a_{1}+a_{2}\right) / p\right\} * V_{T}}\right]-1}
$$

The diode ideality factors $\mathrm{a}_{1}$ and $\mathrm{a}_{2}$ represent the diffusion and recombination current component. The two diode models produce more precise results at lower irradiance levels.

The Matlab/Simulink implementation of the two diode model is as follows:

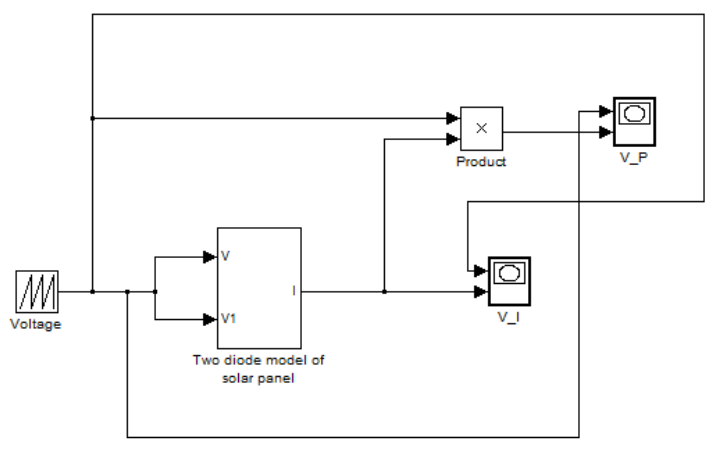

Fig -8: Two Diode Model Matlab/Simulink Implementation

The PV Characteristics under Varying Irradiance and Temperature for a two diode model are shown below:

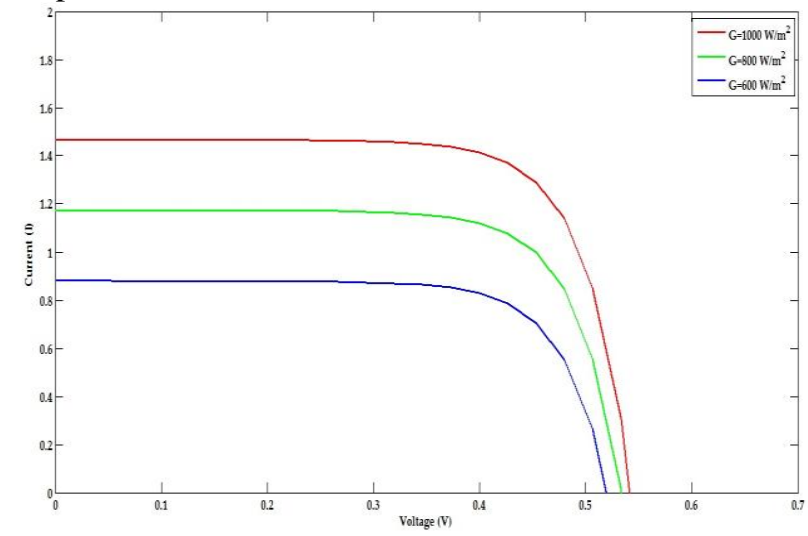

Fig -9: V-I Curve under varying Irradiance

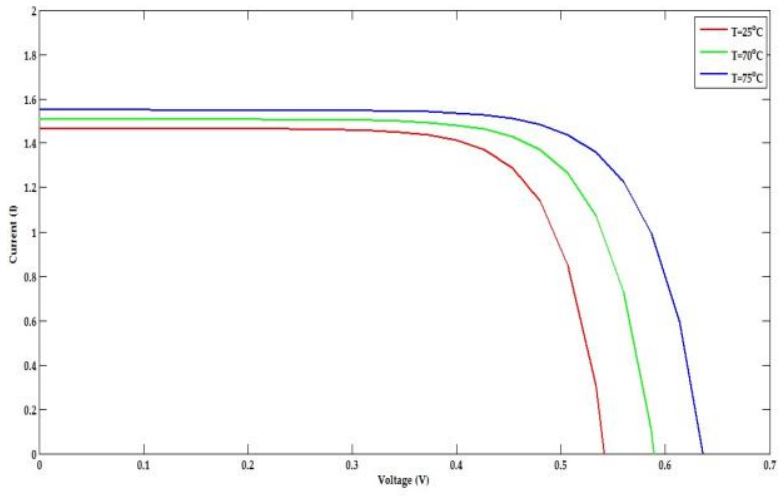

Fig -10: V-I Curve under varying Temperature

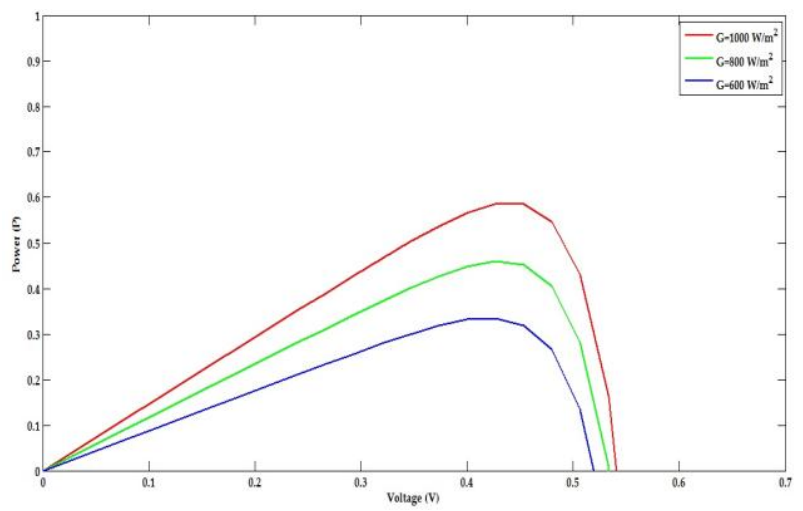

Fig -11: P-V Curve under varying Irradiance

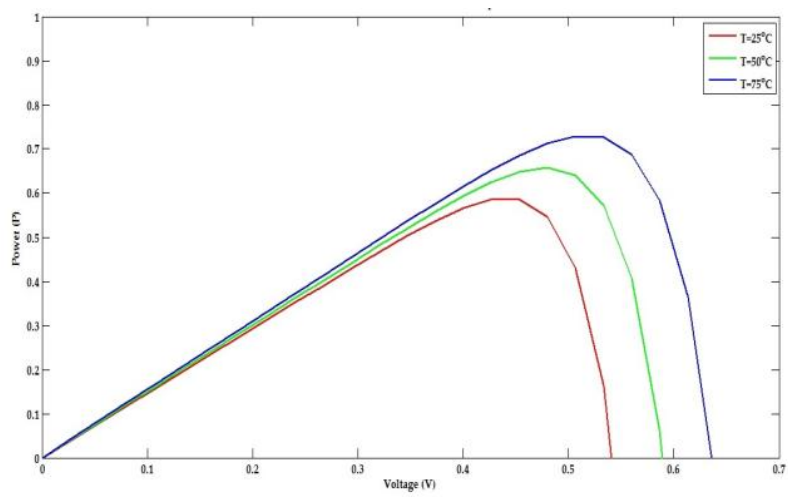

Fig -12: P-V Curve under varying Temperature The Irradiance values given to the solar cell are $1000 \mathrm{~W} / \mathrm{m}^{2}$, $800 \mathrm{~W} / \mathrm{m}^{2}, 600 \mathrm{~W} / \mathrm{m}^{2}$ and the $\mathrm{I}_{\mathrm{sc}}$ values vary proportionately. The Temperature values given are $25^{\circ} \mathrm{C}, 50^{\circ} \mathrm{C}, 75^{\circ} \mathrm{C}$ and the $\mathrm{V}_{\mathrm{oc}}$ values vary with the temperature.

\section{SIMSCAPE MODELLING}

The solar cell block in the Simscape environment represents a solar cell current source. The model includes the following components:-

- $\quad$ Solar-induced current

- Temperature dependence

The block has the following ports:-

- $\quad \mathrm{I}_{\mathrm{r}}$ Incident irradiance

- $\quad+$ Positive electric voltage

- $\quad$ - Negative electrical voltage 


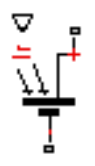

Fig -13: Solar cell model in Simscape

The solar cell in electronics represents single solar cell as a parallel current source $\left(\mathrm{I}_{\mathrm{ph}}\right)$ an exponential diode $\mathrm{D}$ and a shunt resistance $\left(R_{p}\right)$ that are connected in series with a resistance $\left(R_{s}\right)$. The mathematical equations used in the single diode and two-diode model are applicable for the Simscape model as well.

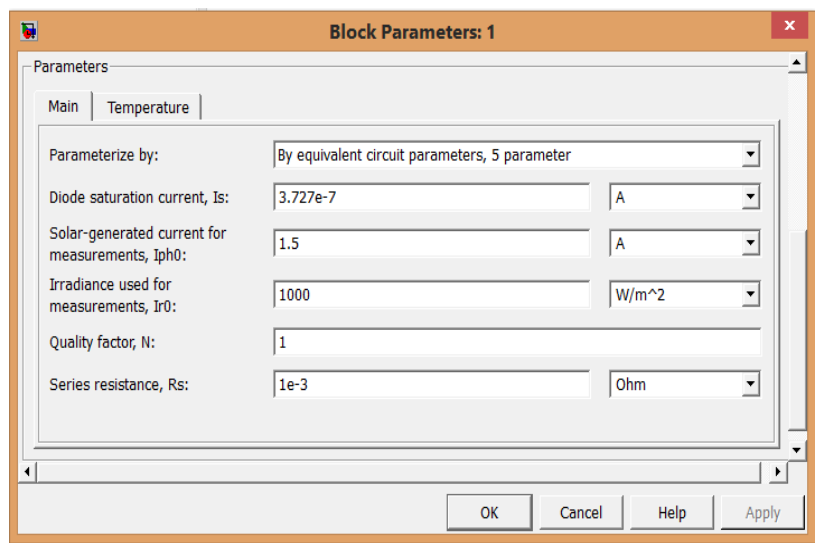

Fig -14: 5-parameter model

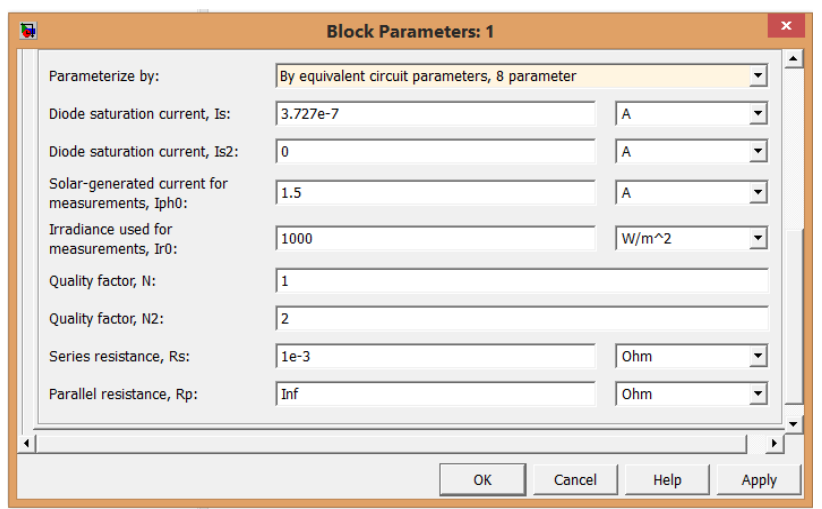

Fig -15: 8-parameter model

The block can be parameterized in terms of short-circuit current and open-circuit voltage. This block allows enclosing one of the two models: a model with eight parameters and a model with five parameters. It is assumed that the impedance of $R_{p}$ is infinite and the saturation current of the second diode is zero. The model with five parameters allows optimization of this block according to the equivalent circuit model parameters or by short circuit current and open circuit voltage.

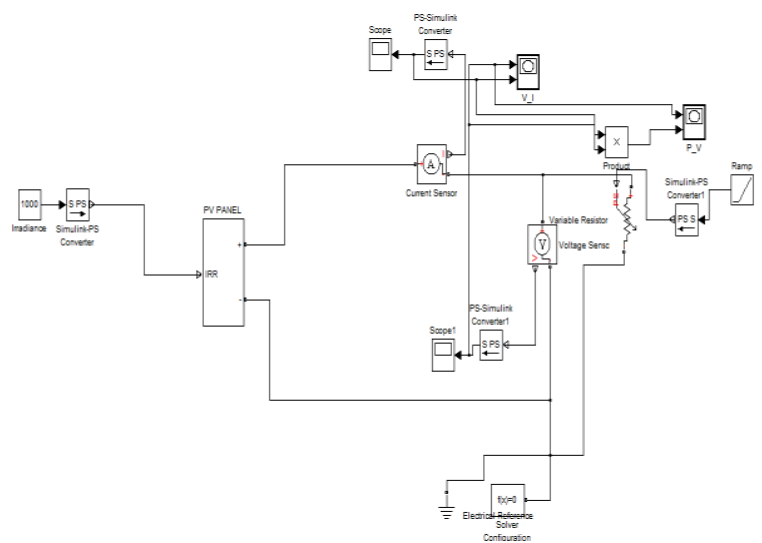

Fig -16: Simscape modelling of a PV cell

\subsection{Simscape Single Diode Modeling (5-Parameter}

Model)

The PV Characteristics under Varying Irradiance and Temperature for a one diode model implemented in Simscape are shown below:

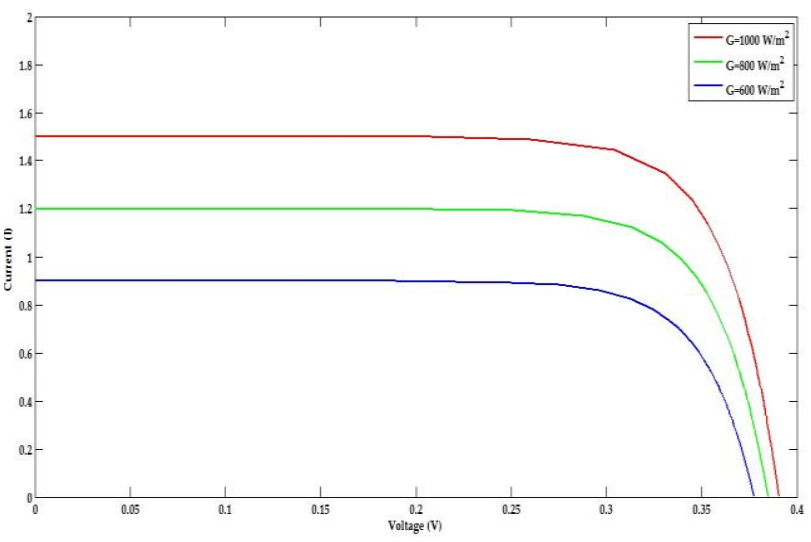

Fig -17: V-I Curve under varying Irradiance

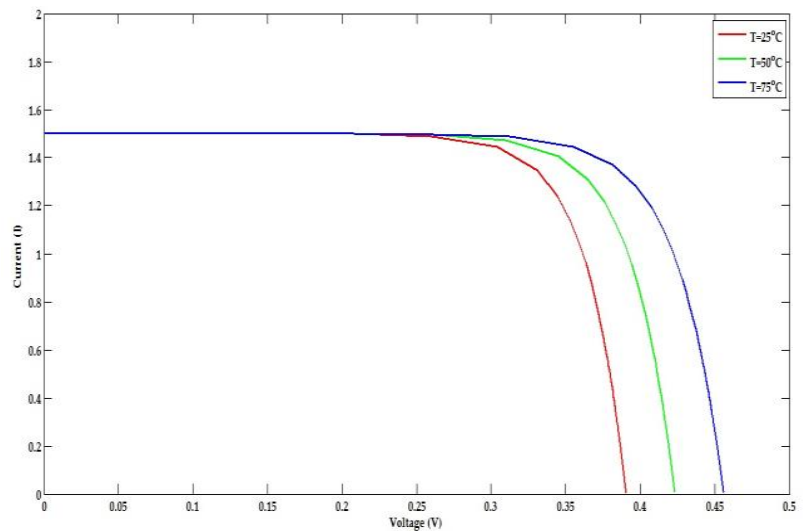

Fig -18: V-I Curve under varying Temperature 


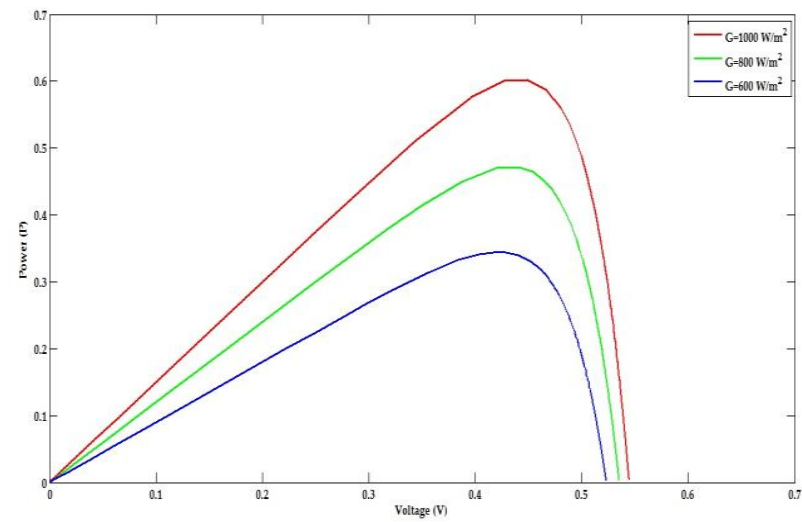

Fig -19: P-V Curve under varying Irradiance

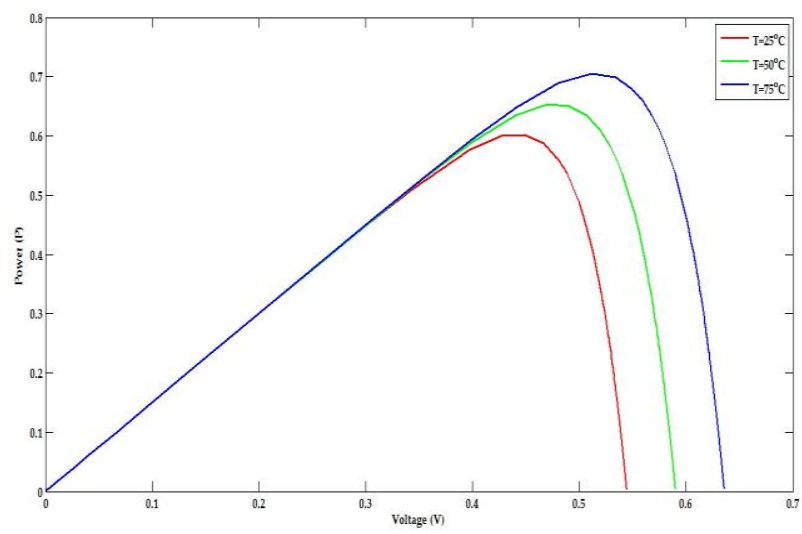

Fig -20: P-V Curve under varying Temperature

\subsection{Simscape Two Diode Modeling (8-Parameter}

\section{Model)}

The PV Characteristics under Varying Irradiance and Temperature for a two diode model implemented in Simscape are shown below:

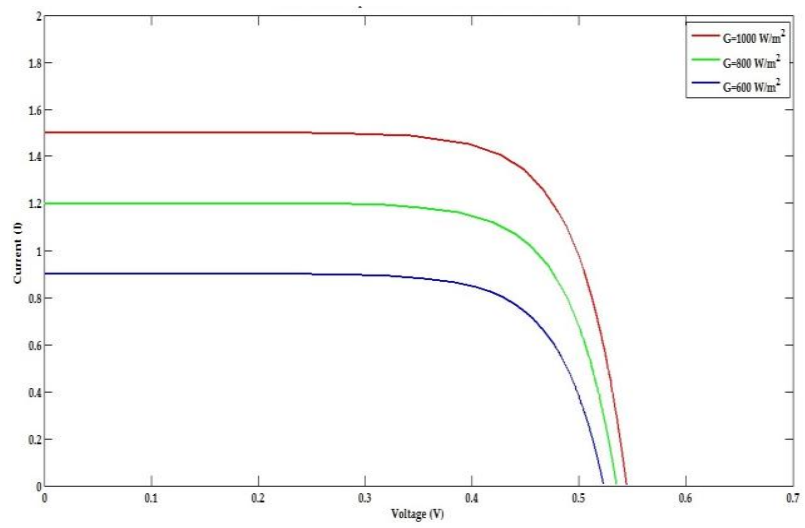

Fig -21: V-I Curve under varying Irradiance

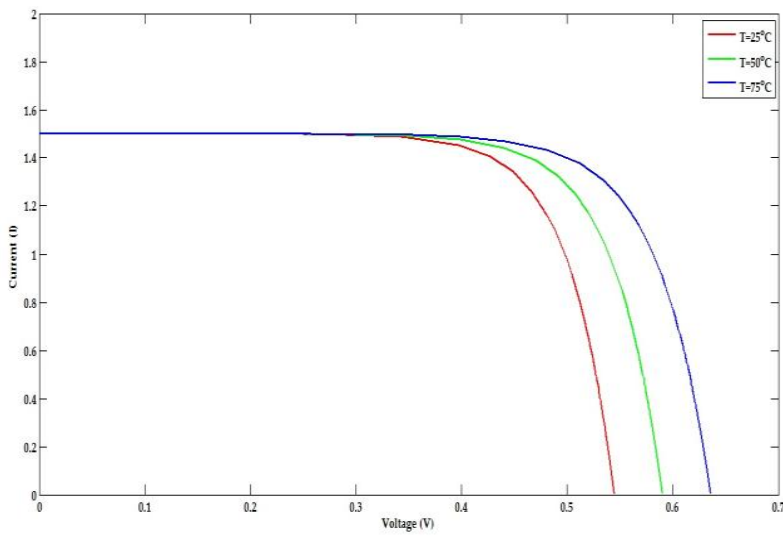

Fig -22: V-I Curve under varying Temperature

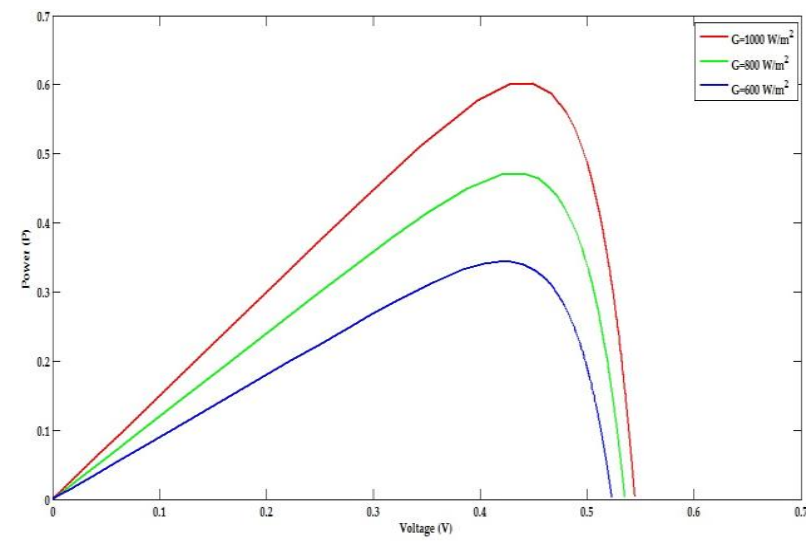

Fig -23: P-V Curve under varying Irradiance

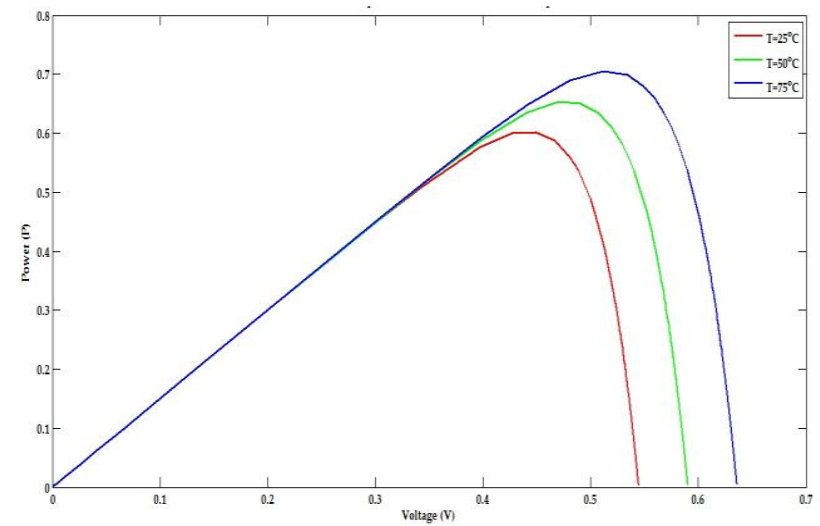

Fig -24: P-V Curve under varying Temperature

The Irradiance values given to the solar cell are $1000 \mathrm{~W} / \mathrm{m}^{2}$, $800 \mathrm{~W} / \mathrm{m}^{2}, 600 \mathrm{~W} / \mathrm{m}^{2}$ and the $\mathrm{I}_{\mathrm{sc}}$ values vary proportionately. The Temperature values given are $25^{\circ} \mathrm{C}, 50^{\circ} \mathrm{C}, 75^{\circ} \mathrm{C}$ and the $\mathrm{V}_{\mathrm{oc}}$ values vary with the temperature.

\section{RESULTS AND DISCUSSIONS}

In order to compare various PV models, a small scale PV cell of 0.8 watts is considered. The four models i.e., mathematical modeling of single diode and two diode model and the Simscape modeling of the single diode and two diode model are simulated and their PV Characteristics are plotted in the Matlab/Simulink environment. The Comparison of the PV Characteristics are shown in the below figure: 


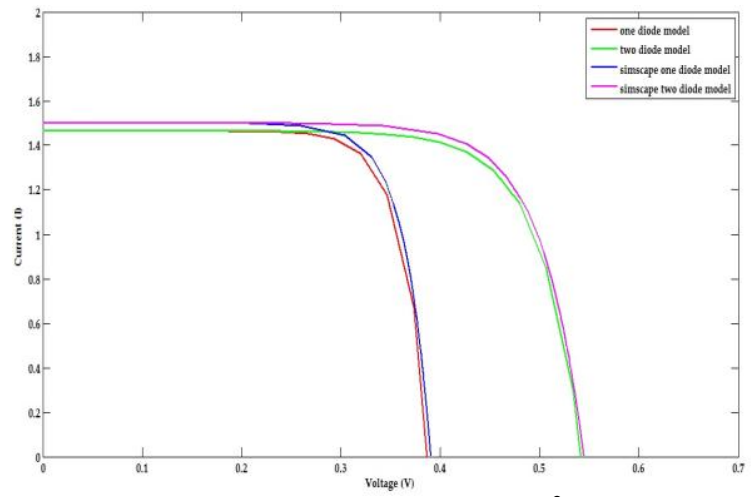

Fig -25: V-I Curves for $\mathrm{G}=1000 \mathrm{~W} / \mathrm{m}^{2}$ and $\mathrm{T}=25^{\circ} \mathrm{C}$

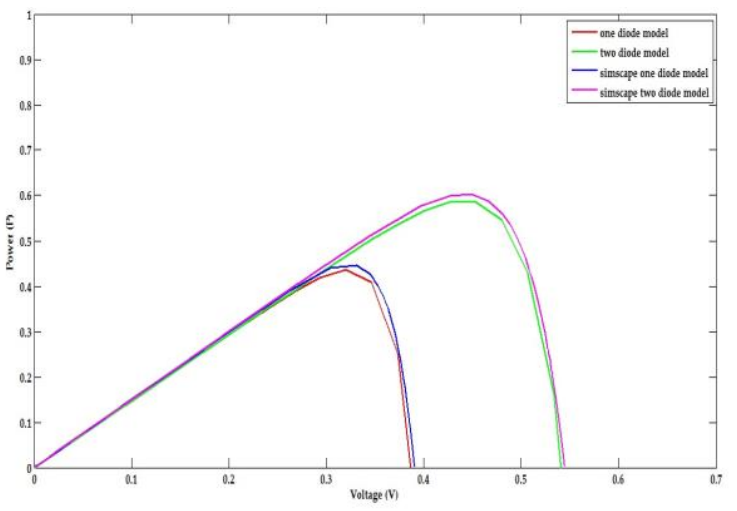

Fig -26 P-V Curves for $\mathrm{G}=1000 \mathrm{~W} / \mathrm{m}^{2}$ and $\mathrm{T}=25^{\circ} \mathrm{C}$

It can be observed from Fig 25 and Fig 26 that the twodiode model gives a better precise output under temperature and irradiation variation, with respect to the single-diode model. This is observed as the single diode models were built on the assumption that the recombination losses were absent in the depletion region, which is not applicable in real solar cell especially at low voltages. The observed difference between the power generated from the single diode and the two diode models is $0.13 \mathrm{~W}$ under STC. It was also found from the plots that PV Simscape model is a more precise tool to simulate the PV systems. The difference between the Simscape modelling and the Mathematical modelling of $0.02 \mathrm{~W}$ under STC. The Simscape based Solar cell focuses mainly on the dynamic output of the solar cells Thus, it is clear that Simscape yields more accurate results than the Mathematical modeling of the PV Cell. The results can be observed from the Tables 3-4.

Table -3: Comparison between One Diode and Two Diode models under varying Temperature and Irradiance conditions

\begin{tabular}{|l|l|l|l|l|l|l|}
\hline \multirow{2}{*}{$\begin{array}{l}\text { Irradiance } \\
(\mathrm{G})\end{array}$} & \multicolumn{9}{|l|}{ One diode model } & \multicolumn{3}{l|}{ Two diode model } \\
\cline { 2 - 7 } & $\mathrm{V}_{\mathrm{oc}}$ & $\mathrm{I}_{\mathrm{sc}}$ & $\mathrm{P}_{\max }$ & $\mathrm{V}_{\mathrm{oc}}$ & $\mathrm{I}_{\mathrm{sc}}$ & $\mathrm{P}_{\max }$ \\
\hline 1000 & & & & & & \\
\hline 800 & 1.333 & 1.464 & 0.435 & 1.333 & 1.464 & 0.585 \\
\hline 600 & 1.333 & 1.171 & 0.342 & 1.333 & 1.171 & 0.460 \\
\hline Temperature $(\mathbf{T})$ and $\mathbf{G}=\mathbf{1 0 0 0} \mathbf{W} / \mathbf{m}^{2}$ & 1.333 & 0.878 & 0.335 \\
\hline $25^{\circ} \mathrm{C}$ & 1.333 & 1.464 & 0.435 & 1.333 & 1.464 & 0.585 \\
\hline $50^{\circ} \mathrm{C}$ & 1.333 & 1.506 & 0.487 & 1.333 & 1.506 & 0.657 \\
\hline $75^{\circ} \mathrm{C}$ & 1.333 & 1.549 & 0.540 & 1.333 & 1.549 & 0.729 \\
\hline
\end{tabular}

Table -4: Comparison between 5-parameter and 8parameter models in SIMSCAPE under varying

Temperature and Irradiance conditions

\begin{tabular}{|c|c|c|c|c|c|c|}
\hline \multirow{2}{*}{$\begin{array}{l}\text { Irradiance } \\
(\mathrm{G}) \\
\mathrm{W} / \mathrm{m}^{2}\end{array}$} & \multicolumn{3}{|c|}{$\begin{array}{l}\text { Simscape } \\
\text { one diode } \\
\text { model }\end{array}$} & \multicolumn{3}{|c|}{$\begin{array}{l}\text { Simscape two diode } \\
\text { model }\end{array}$} \\
\hline & $\mathrm{V}_{\mathrm{oc}}$ & $\mathrm{I}_{\mathrm{sc}}$ & $\mathrm{P}_{\max }$ & $V_{o c}$ & $\mathrm{I}_{\mathrm{sc}}$ & $\mathrm{P}_{\max }$ \\
\hline 1000 & 0.390 & 1.500 & 0.445 & 0.544 & 1.500 & 0.6021 \\
\hline 800 & 0.384 & 1.200 & 0.351 & 0.535 & 1.200 & 0.4713 \\
\hline 600 & 0.377 & 0.900 & 0.258 & 0.523 & 0.900 & 0.3444 \\
\hline \multicolumn{7}{|c|}{ Temperature $(T)$ and $G=1000 \mathrm{~W} / \mathrm{m}^{2}$} \\
\hline $25^{\circ} \mathrm{C}$ & 0.390 & 1.500 & 0.445 & 0.544 & 1.500 & 0.6021 \\
\hline $50^{\circ} \mathrm{C}$ & 0.423 & 1.500 & 0.485 & 0.590 & 1.500 & 0.6529 \\
\hline $75^{\circ} \mathrm{C}$ & 0.456 & 1.500 & 0.522 & 0.636 & 1.500 & 0.7046 \\
\hline
\end{tabular}

\section{CONCLUSION}

Simulation tools are very mandatory for developing and handling mathematical simulations for handling mathematical simulations for analyzing the behavior of PV Systems. They embolden the process of progressing the study of new systems like power converters, inverters etc., for reducing cost and time. In this paper, a study on the various mathematical modeling of PV array is discussed. The models discussed are single diode model, two diode model and Simscape modeling of the 8-parameter and 5parameter model. It can be revealed from the results that the Simscape modelled Solar cells i.e., the single diode and two diode model has comparably better accuracy that the formulated models. The appropriate modeling of the solar cells can facilitate proficient work in the area of MPPT even under varying atmospheric conditions.

\section{REFERENCES}

[1]. Mr. G. Venkateswarlu, Dr.P.Sangameswar Raju "simscape model of photovoltaic cell", International Journal of Advanced Research in Electrical, Electronics and Instrumentation Engineering Vol. 2, Issue 5, May 2013

[2]. B. Chitti Babu, Suresh Gurjar, "A Novel Simplified Two-Diode Model of Photovoltaic (PV) Module", IEEE journal of photovoltaics, Vol. 4, No. 4, July 2014

[3] Kashif Ishaque, Zainal Salam†, Hamed Taheri, "Accurate MATLAB Simulink PV System Simulator Based on a Two-Diode Model", Journal of Power Electronics, Vol. 11, No. 2, March 2011

[4]. Abd Alrahim Shannan, N.M.; Yahaya, N.Z.; Singh, B., "Single-diode model and two-diode model of PV modules: A comparison," Control System, Computing and Engineering (ICCSCE), 2013 IEEE International Conference on, vol., no., pp.210,214, Nov. 29 2013-Dec. 1 2013

[5]. Mohammed S. Ibbini, shadi mansi, mohammed masadeh, eid al hajri, "Simscape Solar Cells Model Analysis and Design", Computer Applications in Environmental Sciences and Renewable Energy, ISBN: 978-960-474-370-4 [6 Sahoo, N.C.; Elamvazuthi, I.; Nor, N.M.; Sebastian, P.; Lim, B.P., "PV panel modelling using Simscape," Energy, Automation, and Signal (ICEAS), 2011 International Conference on , vol., no., pp.1,4, 28-30 Dec. 2011 
[7]. Salam, Z.; Ishaque, K.; Taheri, H., "An improved twodiode photovoltaic (PV) model for PV system," Power Electronics, Drives and Energy Systems (PEDES) \& 2010 Power India, 2010 Joint International Conference on , vol., no., pp.1,5, 20-23 Dec. 2010

[8]. Banal, S.; Anurag, A.; Babu, B.C., "Comparative analysis of mathematical modeling of Photo-Voltaic (PV) array," India Conference (INDICON), 2012 Annual IEEE , vol., no., pp.269,274, 7-9 Dec. 2012

[9]. Bhatnagar, P.; Nema, R.K., "Control techniques analysis of DC-DC converter for photovoltaic application using SIMSCAPE," Power Electronics (IICPE), 2012 IEEE 5th India International Conference on , vol., no., pp.1,6, 6-8 Dec. 2012

[10]. Mahmoud, Soliman A.; Alsari, M.M.; Reda, E.I.; Alhammadi, R.M., "MATLAB modeling and simulation of photovoltaic modules," Circuits and Systems (MWSCAS), 2012 IEEE 55th International Midwest Symposium on , vol., no., pp.786,789, 5-8 Aug. 2012

[11]. Alam, Muhammad Samiul; Mohammad, Mahir Asif; Chowdhury, Riku, "Matlab simscape simulation of an open voltage algorithm based maximum power point tracker for battery charging PV system," Developments in Renewable Energy Technology (ICDRET), 2014 3rd International Conference on the , vol., no., pp.1,6, 29-31 May 2014

[12]. Belhaouas, A.N.; Ait Cheikh, M.S.; Larbes, C., "Suitable Matlab-Simulink simulator for PV system based on a two-diode model under shading conditions," Systems and Control (ICSC), 2013 3rd International Conference on , vol., no., pp.72,76, 29-31 Oct. 2013

\section{BIOGRAPHIES}

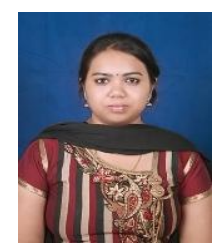

B.SAI PRANAHITA pursuing M.TECH degree in Power Electronics and Drives, from SRM University, Chennai, Tamil Nadu. Her interest of research includes MPPT in PV arrays, Control Systems.

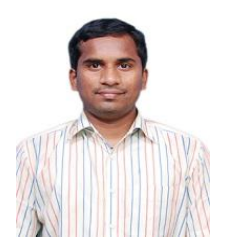

A.SAI KUMAR pursuing M.TECH degree in Power Electronics and Drives at SRM University, Chennai, Tamil Nadu. His areas of interest include Power Electronics Electrical Drives NN applications in Electrical Drives, MPPT in PV arrays.

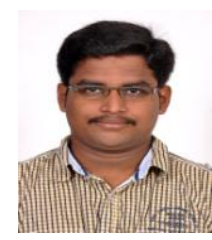

A.PRADYUSH BABU pursuing M.TECH degree in Power Electronics and Drives from SRM University, Chennai, Tamil Nadu. His interest of research includes Maximum Power Point tracking in PV array Converter Topologies. 